\title{
Ethics
}

\section{Unilateral Transfers and a Reinterpretation of Objectivist Ethics}

\section{Eren Orgen}

Then Athena Said: Unilateral Transfers and the Transformation of Objectivist Ethics

Kathleen Touchstone

Lanham, Maryland: University Press of America, 2006

xiii +432 pp., bibliography and index

"The impetus for this book was a statement by David Kelley in his interview with John Stossel on a television special called 'Greed' in which he stated that Michael Milken had done more for humanity than Mother Theresa had," writes Kathleen Touchstone in her preface.

Working through Kelley's statement, Touchstone, a professor of economics, produced a creative and intriguing book on unilateral transfers within the context of Objectivism, a philosophy founded by Ayn Rand. In Then Athena Said: Unilateral Transfers and the Transformation of Objectivist Ethics, Touchstone mainly examines Rand's primary social ethic, the Trader Principle, the bilateral exchange of value between independent equals. Reconsidering Rand's thoughts, she raises many arguments and provides thought-provoking insights especially on charity, reproductivity, retaliation and rights.

Touchstone's work wonderfully combines economic theory's focus on "what is" with ethics' focus on what one "should do." She reinterprets Objectivism through the prism of economics, applying economic tools such as consumer theory, capital theory, game theory, and decision-making under uncertainty to address the questions she raises. In her book, Touchstone mainly concentrates on the writings of Rand, and other Objectivists and neo-Objectivists. She also turns to libertarians and classical liberals for background. Scholars, college

The Journal of Ayn Rand Studies 8, no. 2 (Spring 2007): 285-90. 
students, graduate level students, readers with a background in Objectivist ethics, social philosophy and economics would be interested in this book. To make the book more accessible to an intelligent reader without the economics background, most of the technical economic discussions and almost all of the probability calculations are put in the appendix and the technical economic language is kept to a minimum. The preface with an overview of each chapter and a summary are effective and useful. Throughout the book, the focus is well kept. Although there are some speculations on some cases (Touchstone 2006, 130), the author only develops arguments that are related to the main topic: unilateral transfers within the framework of Objectivist ethics.

Then Athena Said is a well-thought out, well written and well laidout original book. The context is logical and systematic in order, and throughout the book the prose is direct and clear. The title promises essentially what the book delivers. The text provides well-balanced coverage. Touchstone examines forced and voluntary unilateral transfers including theft, murder, charity, bequests, reproductivity, discoveries of basic knowledge, creative works, and inventions, gifts, favors, forgiveness, and retaliation within the context of Objectivist ethics. She provides especially strong cases for reproduction, charity and retribution. She shows that most decisions are between two or more positive values. Given the context of limited time and other resources, individuals must often decide which value to affirm over others; having a second purpose, such as the choice to reproduce, can complicate decision-making (367). Touchstone writes:

Bilateral exchange is voluntary and forms the basis for Rand's principle of justice-the trader principle... There are mutual gains to trade; however, there are incentives to cheat (default, for instance). This incentive structure can be modeled in a Prisoner's Dilemma.... This model is used to analyze the question, why must principles be general-why shouldn't principles have an escape clause that allows for cheating (a forced unilateral transfer) if it can lead to gain? One reason that I examine is the threat of retaliation. Rand's trader principle is broadened to include the principle of reciprocity. $\mathrm{I}$ argue that in an original state of nature, retaliation would 
not only be necessary, it would also be moral (with certain qualifications). (39)

Charity is regarded as a minor virtue in Objectivism as it does not contribute to the survival of the individual giver. According to the Objectivist view, one should not give or receive the unearned except in emergencies. For Rand, humanitarians are not productive. They are not compensated by their beneficiaries and they redistribute income from producers to nonproducers. The Trader Principle is the exchange of value for value (313). However, Touchstone argues that many, if not most, individuals are net beneficiaries. They receive benefits without giving value in return. Touchstone provides further insights on the charity issue and argues that humanitarians could be regarded as productive, and because most individuals receive benefits for which they do not pay or pay fully, it is not a sacrifice to give to charities (326-34). Touchstone provides good examples to support her argument. One is that most individuals benefit from the discoveries of knowledge of others, such as inventions or creative works. Inventors or creators are not fully compensated by their beneficiaries as patents and copyrights are of limited duration and ownership of basic knowledge is not possible because of its public goods nature (327-28). Individuals in free countries have an inheritance of freedom. These people also benefit from those who have established, discovered, defended, and preserved freedom. These benefactors were not fully compensated for their contributions either (329-32). Touchstone argues that because most people have received benefits without paying or fully paying the cost, it is not a sacrifice to make charitable or other philanthropic contributions to others (326-34).

Touchstone makes a credible case that humanitarians can be productive and that other people are an essential part of reality. According to Rand, insofar as the cardinal virtues are concerned, other people are not fundamental. Though Rand deals with individuals in a social context, Touchstone places a primary emphasis on "other people" in that context:

I conclude that other people are a fundamental part of reality. Since I elevate reproduction to be on par with production, this introduces the necessity of (specific) other people in 
one's life. Also, I noted that once all original resources (space) are owned, the only way for a propertyless person to have access to property (moral space) is to trade with others. Other people become a fundamental part of reality in that respect. Values and virtues dealing with others-such as nurturance and justice-become primary. All of the cardinal values and virtues cannot be achieved by a man alone. (372)

In the book, Touchstone also provides a "rule-of-thumb" or heuristic to guide a person's charitable giving. While giving to charity is a personal choice that can be influenced by many factors (including religious beliefs, personal values and passions), such a heuristic might help readers determine the appropriate level of charitable giving. In the appendix, Touchstone provides several probabilities that might be used in the calculation of how much to give to charity (273-74, Appendix 1.11). She writes:

I believe that charity should be elevated to a major virtue; however, because it falls outside of the market mechanism, it is not subject to its self regulating tendency. The information and incentives of the price mechanism are absent. I offer a heuristic for giving, a fraction that is derived from the BUP [Benevolent Universe Premise], the fundamental alternative, and decision theory under uncertainty (risk). (312)

Rand's Benevolent Universe Premise states that if one is rational, one can expect success. Failure is possible, but incidental (342). Except under the most unusual circumstances, an ethical person chooses only among ethical alternatives. Touchstone interprets this to mean that for every decision there is the probability of success and failure and there may be two ways to choose. One is to choose the ethical action only on the basis of the expected gains and ignore the expected loss associated with each decision. The other is to choose actions based on a calculation of the expected gain plus the expected loss (342-43).

Because her background is in economics, Touchstone uses economic tools to address many of these types of ethical questions. 
For instance, while both productivity and value are central to ethics and economics, Touchstone analyzes these two concepts through the lens of the latter. In Chapters Eleven and Twelve, she compares the Objectivist perspective on value, consumption, and productivity with that found in economic theory. She ties the Objectivist view of the way to "earn" an inheritance to a principle of economics related to keeping the value of capital intact (245). She transforms the Objectivist view of inheritance by integrating it with economist Gary Becker's statement that parents may endow their children with physical or human capital (250). She makes the case that to keep one's human capital intact, a person should have children and instill values in his or her children and provide for their education. Therefore, Touchstone concludes that this puts "reproductivity" on a par with productivity within the context of Objectivist ethics (249-60). She also points out that if people do not have children, they may still provide for the maintenance of their values and education by making donations to individuals or institutions (344-45).

Touchstone presents a strong argument for positive rights in addition to those that are typically accepted by Objectivists and classical liberals (106). According to Objectivists and libertarians, positive rights are usually the result of a contract-e. g., trade (119). A person is owed payment by right, if he has met his part of the bargain in an exchange agreement. If the person is supposed to pay defaults on payment, then, Touchstone argues, there has been a forced unilateral transfer, and the person who is owed is entitled to restitution (53). Forced unilateral transfers cover not only default, but all other infringements against an individual's person or property (53-58). If a person's property is "used" or "taken" without his consent by another, then he has a right to compensation or retribution (369-70).

Touchstone argues that Rand believed that people had a right to retaliate, but it was a right they should not exercise. This right should be turned over to the government (48). The government's primary responsibility is rights protection. In Touchstone's view, Rand did not fully explore the theoretical transition from man alone on a desert island to man living among men under government. In Then Athena Said, Touchstone attempts to fill this gap (177). She makes two arguments for the existence of government. Touchstone writes: 
"One relates to a point I made in chapter 7 that, under anarchy those children (and others with diminished capacity) who are abused or neglected by their caregivers would be systematically excluded from rights protection. This violates the equal freedom principle" (177). The second involves a decision under uncertainty; in a state of nature, a person must consider the possibility of being accused of a crime. A person weighs the chances of having his rights violated by another under anarchy relative to a condition in which government is the rights protector (188-90).

Touchstone argues that government is coercive because it does not permit private individuals to retaliate or seek retribution on their own behalf when their rights have been violated. Whereas Objectivists and libertarians oppose taxation because it is coercive, Touchstone argues that taxation is not separate from coercion. She writes: "My argument is that the exchange of the right to retaliation for protection (the social contract) requires that government produce protection. Production requires the use of scarce resources. Production and income are inseparable. Funding is not separate from, but integral to, that which is exchanged. The coercive aspect of the exchange is that one relinquishes his right to protection. Funding is not a separate coercive aspect, but part and parcel of the exchange. Without funding, the exchange is incomplete and empty" (178).

Then Athena Said is a thought-provoking book with valuable insights and well-developed arguments on reproductivity, charity, retribution, and how much to give to charity. In some cases, however, readers might find speculations without complete arguments. For instance, Touchstone suggests that there may be some basis for rights other than human rationality, such as, the ability to experience pain (as related to "cruel and unusual punishment") (130). I think Touchstone does not develop certain speculations; some other arguments are also too far off the main topic to keep the focus. Yet, her detailed work provides further guidance on unilateral transfers, especially on charity, retribution and rights. Overall, it is to Touchstone's credit to have filled some gaps in Objectivism's primary social ethic, the Trader Principle. I think the book provides valuable contributions to the social philosophy and is a good source of reference to readers interested in Objectivist ethics. 